\title{
Characterization of topology-, gestation- and labor-related changes of a cassette of myometrial contraction-associated protein mRNA in the pregnant baboon myometrium
}

\author{
W X Wu, X H Ma, Q Zhang and P W Nathanielsz \\ Laboratory for Pregnancy and Newborn Research, College of Veterinary Medicine, Cornell University, Ithaca, New York 14853, USA \\ (Requests for offprints should be addressed to P W Nathanielsz, Laboratory for Pregnancy and Newborn Research, Department of Biomedical Sciences, \\ College of Veterinary Medicine, Cornell University, Ithaca, New York 14853-6401, USA; Email: pwn1@cornell.edu)
}

\begin{abstract}
Our objective was to examine the topology-, gestationand labor-related changes of estrogen receptor (ER) $\alpha$, progesterone receptor (PR), oxytocin receptor (OTR) and thrombospondin-1 (TSP1) mRNA in pregnant baboon myometrium.

ER $\alpha$, PR, OTR and TSP1 mRNAs extracted from the lower uterine segment and fundal myometrium of pregnant baboons not in labor between 121 and 180 days of gestational age $(n=9)$ and in established spontaneous labor between 164 and 193 days of gestational age $(n=5)$ were analyzed by Northern blot.

There were no topology-, gestation- or labor-related changes of ER $\alpha$ and PR mRNA in or between the lower uterine segment or/and the fundus. OTR mRNA was the same in the lower uterine segment and the fundus from baboons not in labor and non-labor fundal, but not lower uterine segment, myometrial OTR mRNA increased with gestation $\left(\mathrm{R}^{2}=0 \cdot 81, P<0 \cdot 05\right)$. Fundal OTR mRNA
\end{abstract}

rose significantly compared with the lower uterine segment during spontaneous labor. TSP1 mRNA increased significantly in both the fundus and lower uterine segment during labor. TSP1 mRNA in the lower uterine segment during spontaneous labor was higher than in the fundus during spontaneous labor.

In conclusion, fundal and lower uterine segment ER $\alpha$ and PR mRNA remained unchanged in late gestation and spontaneous labor. The increased OTR mRNA may serve as a mechanism to increase uterine sensitivity to OT during late gestation. The higher fundal OTR mRNA compared with the lower uterine segment provides polarity which assists fetal expulsion by uterine contractions during labor. The significance of increased TSP1 mRNA during labor may relate to homeostasis and merits further study.

Journal of Endocrinology (2001) 171, 445-453

\section{Introduction}

Preparation of the myometrium associated with labor involves the appearance of a cassette of myometrial contraction-associated proteins (mCAPs). The genes for these proteins are up-regulated or down-regulated at labor (Lye 1994, Zingg et al. 1995, Wu et al. 1998). Each member of the cassette of genes contributes to some extent to the switch in myometrial contractility patterns from contractures to contractions as well as the progression of established labor. The nature of the change in myometrial contractile patterns differs from species to species. In sheep, one of the most extensively studied experimental models, myometrial activity switches from contractures to contractions only once, $12-24 \mathrm{~h}$ before delivery. In contrast, in non-human primates and pregnant women, the switch from contractures to contractions occurs at night and generally recurrs for several nights before delivery (Taylor et al. 1983). Altered abundance of members of this cassette of genes in the myometrium is a prerequisite for normal labor and delivery. Myometrial activation before and during labor appears to play a critical role in connecting fetal signals that indicate fetal readiness for birth to maternal factors that carry labor forward to produce safe delivery of the fetus. It is important to evaluate these events in non-human primates as well as sheep.

Healthy uterine tissues obtained at precise times in relation to the onset of labor and suitably processed for study are required to permit evaluation of molecular changes associated with labor. It is difficult to obtain the necessary range of hysterectomy specimens from healthy pregnant women. To obtain information regarding the topology of the critical mCAPs it is necessary to obtain tissues from different regions of the uterus. There are now increasing data from both human and animal studies to suggest that the expression of a range of mCAPs is spatially regulated within the uterus (Fuchs et al. 1984, Smith et al. 1998, Sparey et al. 1999). For all of these reasons, normal 
non-human primate tissues are indispensable to a better understanding of human parturition. The baboon and other non-human primates share similarities with pregnant women in their reproductive anatomy, physiology and endocrinology throughout pregnancy and during labor.

Both estrogen and progesterone play important roles in preparing the myometrium for labor (Challis \& Lye 1994, Nathanielsz et al. 1994, 1998). The balance between estrogen and progesterone is a key factor that maintains uterine quiescence (Csapo 1975) throughout pregnancy. In a large number of different species, it has been clearly shown that increased estrogen production is associated with delivery (Nathanielsz et al. 1994, 1998). Infusion of androgen to pregnant rhesus monkeys in late gestation to provide a precursor for placental estrogen synthesis will initiate premature delivery (Mecenas et al. 1996). Inhibition of androgen conversion to estrogen will inhibit premature delivery (Nathanielsz et al. 1998). The effects of estrogen and progesterone are mediated through estrogen and progesterone receptors (Carson-Jurica et al. 1990). Alterations in estrogen receptor (ER) and progesterone receptor (PR) concentrations may also play an important role in the changing responses of the myometrium to estrogen and progesterone.

The oxytocin (OT) receptor (OTR) is another important mCAP which has been studied extensively in association with labor in the rat (Zingg et al. 1995, Ou et al. 1998), sheep (Wu et al. 1996c), and pregnant women (Fuchs et al. 1984). No information is available on the important issue of precise topological distribution of OTR in the non-human primate uterus. Such information is of considerable value for understanding OT physiology in human parturition. Our own studies in the rhesus monkey (Giussani et al. 1996) and baboon (Nathanielsz et al. 1997), and those of others in pregnant women (Goodwin et al. 1996) clearly demonstrate a role for OT during labor. In pregnant women, increased sensitivity of the pregnant uterus to OT parallels an increased concentration of myometrial OTR (Zeeman et al. 1997).

We have previously used suppression subtractive hybridization to identify a parturition-related increase in mRNA and protein in one extracellular matrix protein, thrombospondin-1 (TSP1), in the pregnant ovine myometrium (Wu et al. 1999a). Our data suggest that changes in uterine extracellular matrix proteins might also play an important role associated with myometrial activation during labor. We therefore determined whether similar changes in TSP1 mRNA occurred in the pregnant baboon myometrium associated with the onset of labor.

\section{Materials and Methods}

\section{Animals}

Pregnant baboons were obtained from the Southwest Foundation for Biomedical Research (San Antonio, TX,
USA). They had been harem mated and gestational age was confirmed by comparing ultrasonography measurements with records of sex skin swelling. Cesarean section hysterectomy was performed with the animals under halothane general anesthesia in nine baboons not in labor at the following gestational ages: 121, 146, 153, 158, 162, $162,177,177$, and 180 days (term 175-178 days) and eight baboons in spontaneous labor at the following gestational ages: 164, 172, 184, 191, and 193 days. Samples of myometrium were obtained from different regions of the uterus. Uterine electromyographic (EMG) leads had been previously sited in three of eight animals not in labor and the five baboons in spontaneous labor. Animal care and EMG recording and analysis have been described elsewhere (Morgan et al. 1992). Myometrial activity was monitored continuously and evaluated as being either in the low amplitude, infrequent contracture mode (not in labor group), or in the frequent short duration labor type contraction mode (spontaneous labor group) with cervical effacement and dilation. No drugs in any form had been administered to any of the animals in the 2 weeks before surgery. All procedures were approved by the Cornell University Institutional Animal Care and Use Committee, and the facilities were approved by the American Association for the Accreditation of Laboratory Animal Care.

Samples were dissected immediately after removal of the uterus and flash frozen for later extraction of RNA. The fundus was defined as the portion of the uterus immediately superior to the upper limit of the uterine cavity. The lower uterine segment was defined as the portion of the uterus superior to the internal os of the cervix. The upper limit of the lower uterine segment was a line $1 \mathrm{~cm}$ superior to the internal os of the cervix and the lower limit was the internal os itself.

\section{Northern blot analysis}

Poly-A RNA was extracted from flash-frozen myometrial samples stored at $-80{ }^{\circ} \mathrm{C}$ by oligo dT cellulose affinity chromatography using a commercial kit (Fast Track 2.0; Invitrogen, San Diego, CA, USA). The poly-A RNA purity and recovery of each tissue was determined by UV spectrophotometer $(260$ and $280 \mathrm{~nm})$. There were no differences in the yield of RNA per mg tissue between baboons in labor and baboons not in labor.

Samples of poly-A RNA ( $2 \mu \mathrm{g} / \mathrm{lane})$ from each tissue were denatured in $17 \cdot 4 \%(\mathrm{v} / \mathrm{v})$ formaldehyde, $50 \%(\mathrm{v} / \mathrm{v})$ formamide, $20 \mathrm{mM} 3$-(N-morpholino) propanesulfonic acid (MOPS), $5 \mathrm{mM}$ sodium acetate and $1 \mathrm{mM}$ EDTA, $\mathrm{pH} 7 \cdot 0$ for $5 \mathrm{~min}$ at $65{ }^{\circ} \mathrm{C}$ and separated on a $1 \%(\mathrm{w} / \mathrm{v})$ agarose $/ 0.66 \mathrm{M}$ formaldehyde gel. After electrophoresis, RNA was transferred to a nylon membrane (Gene Screen Plus; New England Nuclear, Dupont, Wilmington, DE, USA) by capillary blotting for $24 \mathrm{~h}$ in $10 \times$ SSC $(1 \times$ SSC is $0.15 \mathrm{M} \mathrm{NaCl}$ and $0.015 \mathrm{M} \mathrm{Na}$ citrate, $\mathrm{pH} 7 \cdot 0)$. 

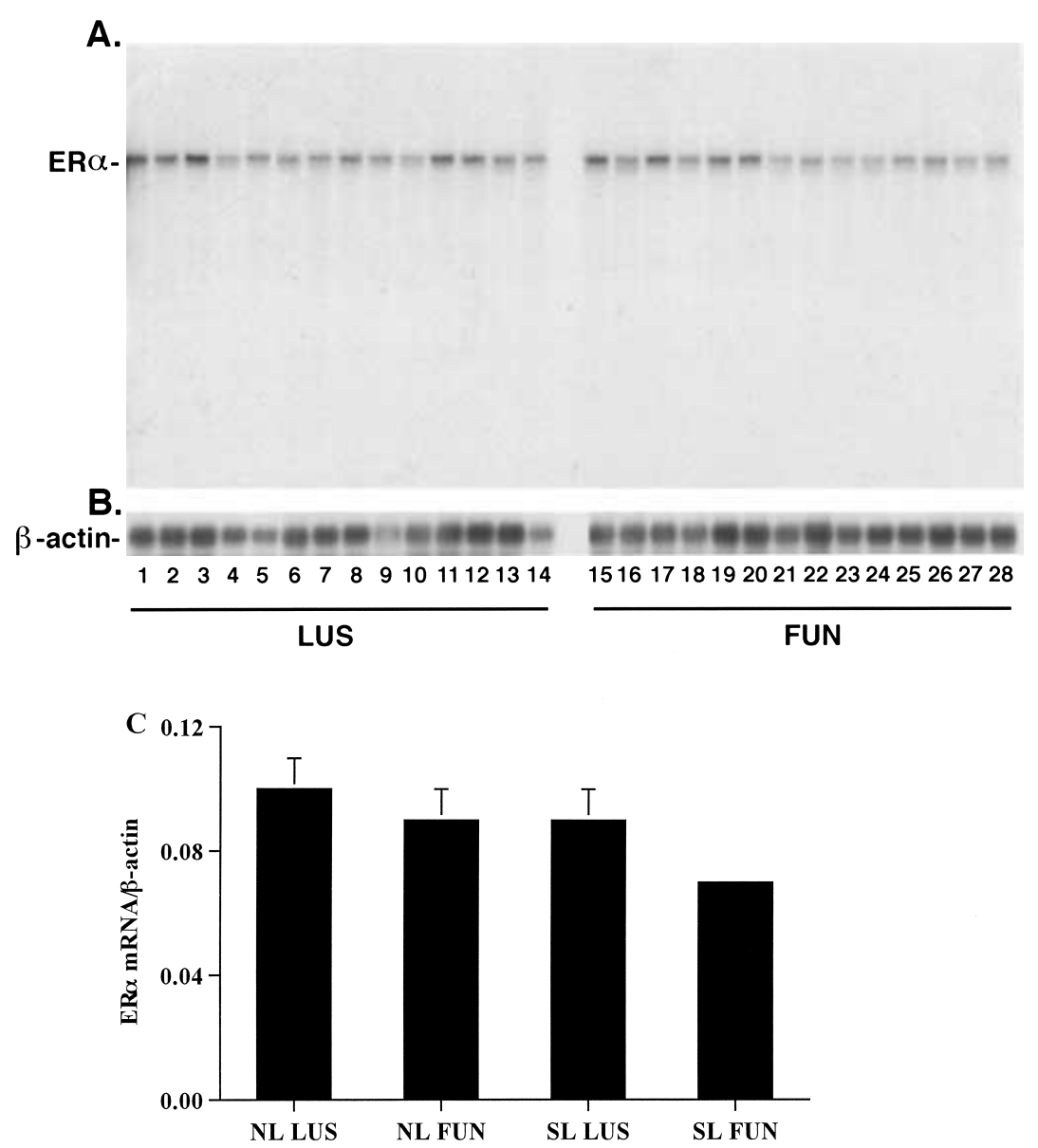

Figure 1 (A) Northern analysis of ER $\alpha$ mRNA in non-labor (NL) lower uterine segment (LUS; lanes 1-9) and NL fundus (FUN; lanes 15-23) compared with spontaneous labor (SL) LUS (lanes 10-14) and SL FUN (lanes 24-28). (B) The same blot was probed for $\beta$-actin. (C) Densitometric analysis of the ratio of ER $\alpha$ and $\beta$-actin mRNA in NL LUS and NL FUN (means \pm S.E.M.; $n=9$ for both groups) compared with SL LUS and SL FUN (means \pm S.E.M.; $n=5$ for both groups). There were no changes of ER $\alpha$ between animals in NL and SL and there were no changes of ER $\alpha$ distribution between LUS and FUN.

Membranes were prehybridized at $42{ }^{\circ} \mathrm{C}$ for $5 \mathrm{~h}$ in hybridization solution $(50 \%(\mathrm{v} / \mathrm{v})$ deionized formamide, $50 \mathrm{mM}$ sodium phosphate, $0.8 \mathrm{M} \mathrm{NaCl}, 2 \% \quad(\mathrm{w} / \mathrm{v})$ sodium dodecyl sulphate (SDS), $100 \mu \mathrm{g}$ salmon sperm $\mathrm{DNA} / \mathrm{ml}, \quad 20 \mu \mathrm{g} \quad \mathrm{tRNA} / \mathrm{ml}$ and $1 \times$ Denhardt's $(50 \times=1 \%$ solution of bovine serum albumin, Ficoll, and polyvinylpyrrolidone).

A $131 \mathrm{bp}$ cDNA probe encoding part of the sheep endometrial OTR, which was generated by PCR, was kindly made available to us by Dr A P F Flint (University of Nottingham, Nottingham, Notts, UK). Recombinant human ER $\alpha$ cDNA containing the entire coding region was kindly made available by Dr P Chambon (University of Strasbourg, Strasbourg, France). Human PR cDNA probe was made available to us by Dr B W O'Malley (Baylor College of Medicine, Houston, TX, USA). Ovine
TSP1 cDNA probe was cloned in our laboratory (Wu et al. 1999a). The cDNA probes were labeled with $\alpha^{32} \mathrm{P}$ dCTP using the random priming method (NEN-Dupont) to specific activities of approximately $1 \times 10^{9}$ c.p.m. $/ \mu \mathrm{g}$. Labeled cDNA was utilized at a final concentration of $1 \times 10^{6}$ c.p.m. specific probe $/ \mathrm{ml}$ hybridization solution.

Hybridization was carried out at $42{ }^{\circ} \mathrm{C}$ for $20 \mathrm{~h}$. Membranes were washed sequentially in $2 \times \mathrm{SSC}$ at room temperature for $10 \mathrm{~min}$, and $0 \cdot 2 \times \mathrm{SSC}$ with $0 \cdot 1 \% \mathrm{SDS}$ at $65{ }^{\circ} \mathrm{C}$ for $30 \mathrm{~min}$. Kodak X-OMAT AR film was exposed to the membrane with intensifying screens at $-80{ }^{\circ} \mathrm{C}$. Exposure durations were varied to achieve hybridization signals within the limited linear range for densitometry. After probing for the receptor gene of interest, membranes were rehybridized with a $\alpha^{32} \mathrm{P}$-labeled cDNA probe encoding $\beta$-actin to normalize each of $\operatorname{ER} \alpha, \operatorname{PR}$, 


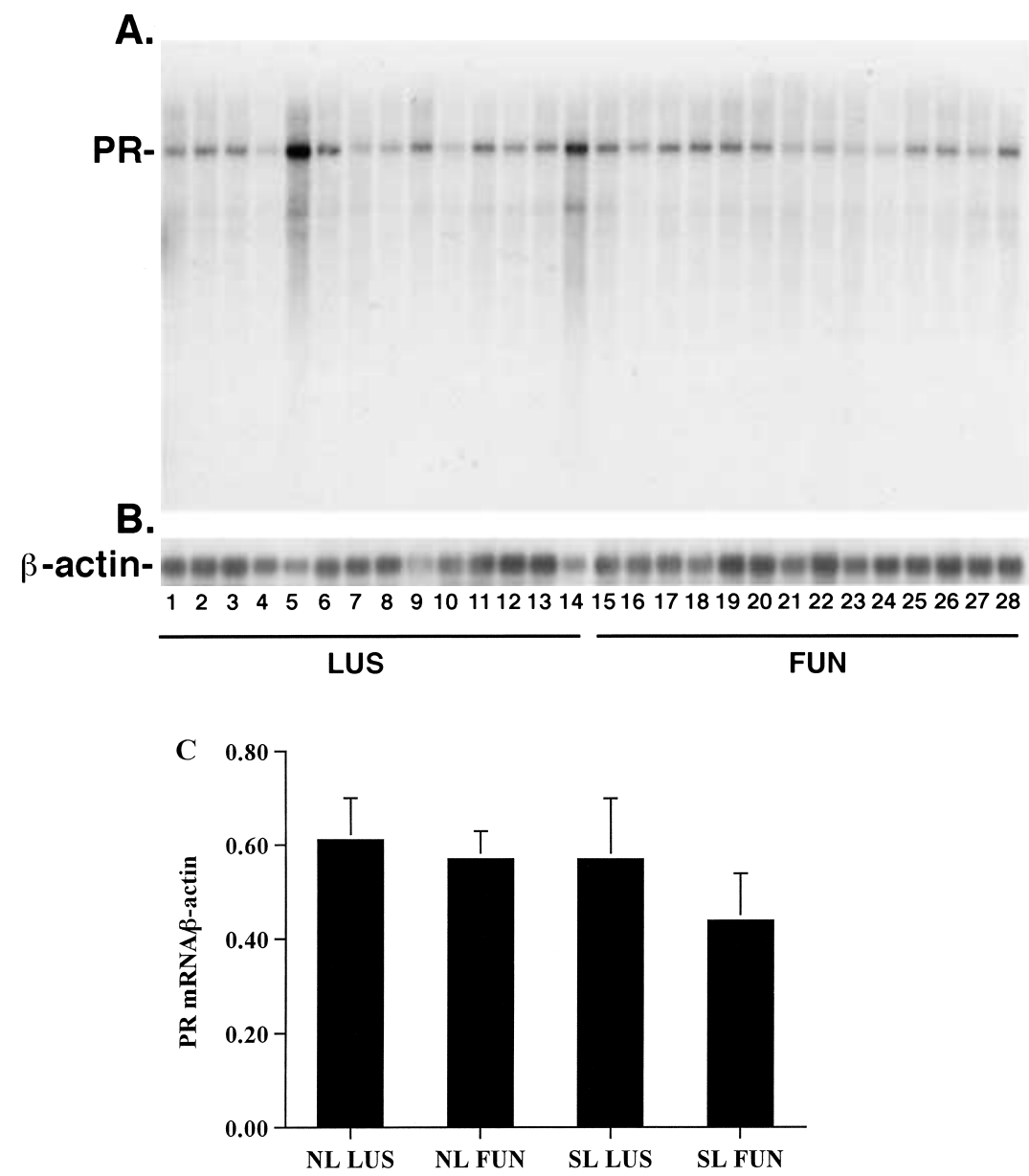

Figure 2 (A) Northern analysis of PR mRNA in non-labor (NL) lower uterine segment (LUS; lanes 1-9) and NL fundus (FUN; lanes 15-23) compared with spontaneous labor (SL) LUS (lanes 10-14) and SL FUN (lanes 24-28). (B) The same blot was probed for $\beta$-actin. (C) Densitometric analysis of the ratio of PR and $\beta$-actin mRNA in NL LUS and NL FUN (means \pm S.E.M.; $n=9$ for both groups) compared with SL LUS and SL FUN (means \pm S.E.M.; $n=5$ for both groups). There were no changes of PR during SL and there were no changes of PR distribution between LUS and FUN.

OTR and TSP1 mRNA levels. Poly-A gel stained with ethidium bromide was also used to monitor the poly-A RNA loading. Autoradiograph signals were analyzed and quantified with a scanner (ScanMaker II; Microtek, Pt Washington, NY, USA) and data were analyzed in a power Macintosh computer $(8100 / 80)$ with a densitometry program (Scan Analysis; Biosoft, Cambridge, Cambs, UK).

\section{Statistical analysis}

Comparison of two means was made with the Student's $t$-test. Comparison of three or more means was made by analysis of variance, and multiple post hoc comparisons were made with Tukey's method for estimating the 95\% confidence interval of pairwise differences. Statistical significance was assumed at the 5\% level. The changes associated with gestation were analyzed by regression analysis. Data are presented throughout as means \pm S.E.M.

\section{Results}

The expression of $E R a$ and $P R$ in the myometrium

Northern blot analysis of poly-A RNA from the pregnant baboon myometrium revealed a single transcript for ER $\alpha$ and PR with approximate molecular weights at $6.2 \mathrm{~kb}$ (Fig. 1) and $11.0 \mathrm{~kb}$ (Fig. 2) respectively. There were no gestational- or labor-related changes for ER $\alpha$ and PR in either the lower uterine segment or the fundus (Figs 1 and 

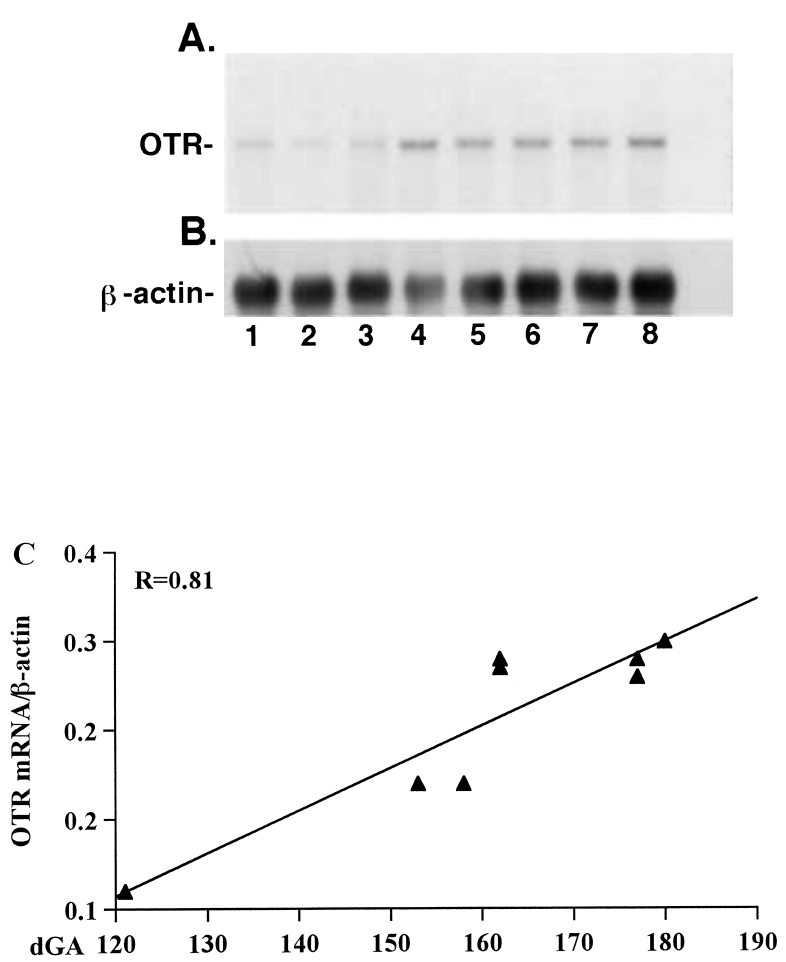

Figure 3 (A) Gestational-associated changes in the abundance of OTR mRNA in non-labor fundus (lanes 1-8) obtained from baboons at the following gestational age in days (dGA): 121 (lane 1), 153 (lane 2), 158 (lane 3), 162 (lane 4), 162 (lane 5), 177 (lane 6), 177 (lane 7), and 180 (lane 8). (B) The same blot was rehybridized with a $\beta$-actin probe to demonstrate relative amounts of RNA in each lane. (C) Densitometric analysis of the ratio of OTR and $\beta$-actin mRNA as a function of the gestational age. There was a significant increase of OTR mRNA in non-labor fundus associated with increased gestational age $(P<0 \cdot 01)$.

2). In addition, there was no differential regional distribution of ER $\alpha$ and PR in the lower uterine segment compared with the fundus (Figs 1 and 2).

\section{The expression of OTR in the myometrium}

There was a major RNA transcript at $6.6 \mathrm{~kb}$ similar to the size of the ovine OTR transcript (Wu et al. 1996c), which hybridized with the OTR cDNA probe (Figs 3 and 4). There was a significant increase of non-labor fundal, but not lower uterine segment, myometrial OTR mRNA associated with increased gestational age $\left(\mathrm{R}^{2}=0 \cdot 81\right.$, $P<0 \cdot 01$, Fig. 3). OTR mRNA in myometrium was significantly higher in the fundus when compared with the lower uterine segment during spontaneous labor but the difference was not significant prior to labor. Since there was no increase in the fundus as a result of labor the difference between the lower uterine segment and the fundus at the time of labor likely reflects, at least in part, a fall in OTR mRNA in the lower uterine segment (Fig. 4).
The expression of TSP1 in the myometrium

TSP1 mRNA was well expressed in the pregnant baboon myometrium as an approximate $6.5 \mathrm{~kb}$ TSP1 mRNA transcript in the myometrium (Fig. 5). There were no gestational-related increases for TSP1 mRNA in either lower uterine segment or fundus (Fig. 5). TSP1 mRNA increased significantly in both fundus and lower uterine segment myometrium during labor and fundal TSP1 mRNA was significantly lower than the lower uterine segment during labor (Fig. 5).

\section{Discussion}

The balance of the action of estrogen and progesterone is important in regulating the extensive morphological, biochemical and physiological changes in the pregnant uterus. These steroids are also essential to suppress myometrial activity, control uterine blood flow and maintain the pregnancy as well as to switch the myometrial contraction patterns that occur at the end of pregnancy (Nathanielsz 1998). Effects of estrogen and progesterone are dependent upon the expression of ER and PR. There are two subtypes of ER, ER $\alpha$ and ER $\beta$ (Kuiper et al. 1996). The different receptor subtypes may have tissue-specific and physiological-state specific actions. The present study focused on ER $\alpha$, the 'classical' form of ER (Green et al. 1986).

The current study is the first to examine topological-, gestational- and labor-associated changes of the $\operatorname{ER} \alpha$ and PR mRNA in the pregnant baboon myometrium. There were no changes of ER $\alpha$ in the pregnant baboon myometrium associated with gestation and labor. This observation is consistent with previous reports in rhesus monkey myometrium analyzed by binding assay (Novy \& Haluska 1994) and immunohistochemistry (Haluska et al. 1990) and our own data obtained by RT-PCR (Wu et al. 2000).

In contrast, a dramatic increase of ER $\alpha$ mRNA occurs in sheep associated with both spontaneous term labor (Wu et al. 1995) and glucocorticoid-induced premature labor (Wu et al. 1996a). We and others have clearly demonstrated that estradiol up-regulates ER $\alpha$ expression and progesterone down-regulates ER $\alpha$ expression in nonpregnant uterine tissues in sheep (Wu et al. 1996b), mouse (Bergman et al. 1992), rhesus monkey (Okulicz et al. 1993) and a human breast cancer cell line (Cho et al. 1991). In addition, the observation that uterine ERs are increased by the PR antagonist RU486 in late gestation in the pregnant rhesus monkey is another example of progesterone's suppressive effect on uterine ER $\alpha$ (Haluska et al. 1990). These results suggest that the control of uterine ER $\alpha$ is dependent on the complex interplay of estrogen and progesterone. In sheep, the sharply increased maternal plasma estradiol concentration (Challis 1971) and decreased maternal plasma progesterone (Thorburn et al. 1988) that occur immediately before parturition may together be 

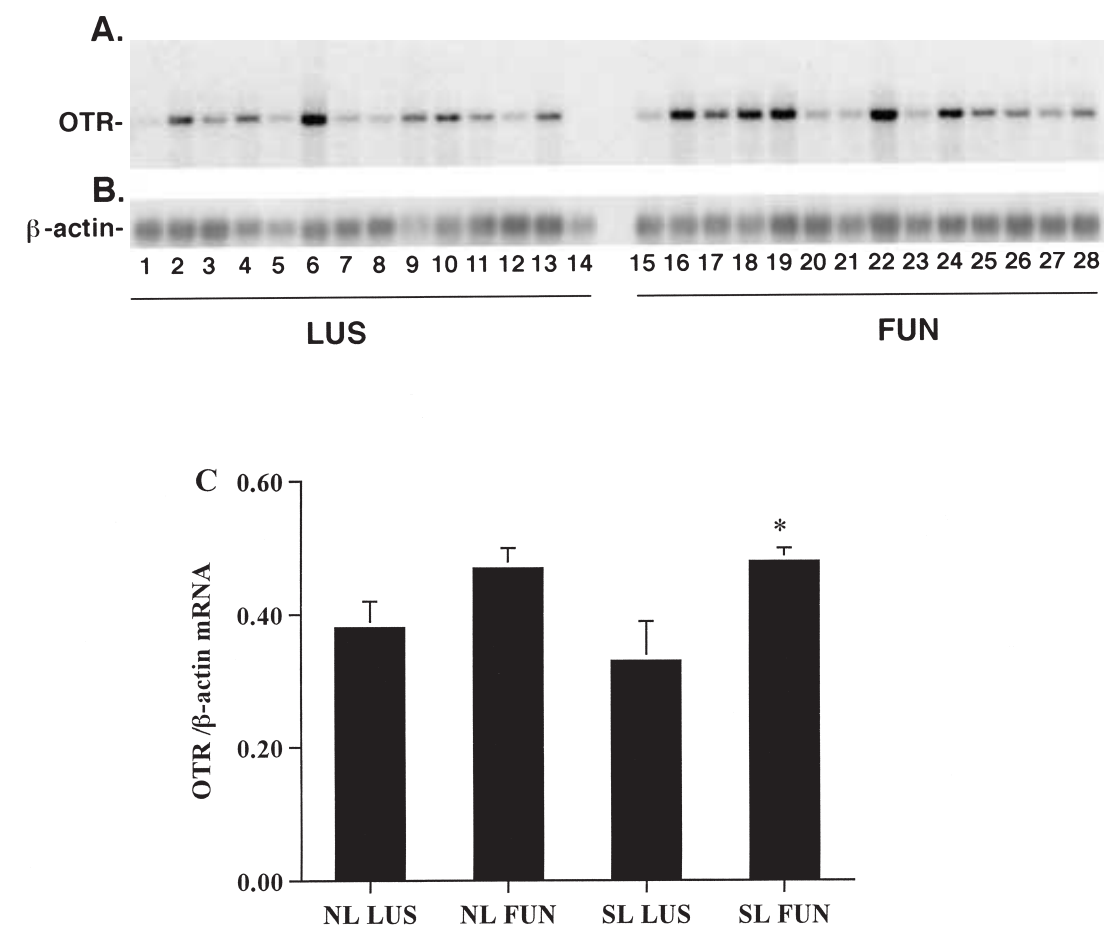

Figure 4 (A) Northern analysis of OTR mRNA in non-labor (NL) lower uterine segment (LUS; lanes 1-9) and NL fundus (FUN; lanes 15-23) compared with spontaneous labor (SL) LUS (lanes 10-14) and SL FUN (lanes 24-28). (B) The same blot was probed for $\beta$-actin. (C) Densitometric analysis of the ratio of OTR and $\beta$-actin mRNA in NL LUS and NL FUN (means \pm S.E.M.; $n=9$ for both groups) compared with SL LUS and SL FUN (means \pm S.E.M.; $n=5$ for both groups). OTR mRNA was the same in NL LUS and NL FUN. However, there was a significant increase in OTR mRNA in FUN compared with LUS during $S L\left({ }^{*} P<0 \cdot 05\right)$.

responsible for increased expression of uterine ER $\alpha$ during labor. In contrast, in non-human primates and pregnant women, the increase of estrogen throughout late gestation is gradual and progesterone concentration in maternal plasma is maintained during labor (Simpson \& MacDonald 1981). These differences in maternal hormone environment may explain the interesting species differences we describe here in ER $\alpha$ mRNA during pregnancy and labor in the baboon.

Much less is known about physiological changes in PR concentration, regulation and function in the myometrium throughout pregnancy and during labor. Quantification of $\mathrm{PR}$ in pregnant intrauterine tissues is difficult, in part due to a very low abundance of PR at the mRNA and protein level. The low abundance of the PR transcript was overcome in the present study using poly-adenylated RNA which provided a signal for PR well above the detectable sensitivity (Fig. 2). The lack of a fall in either peripheral plasma progesterone or myometrial PR mRNA speaks against a simple view of progesterone withdrawal as a major factor in the events leading to parturition in the baboon. In sheep, there is a fall in progesterone prior to labor but no similar change occurs in primates (Liggins et al. 1973); however, replacement of progesterone to late-gestation physiological levels cannot arrest the initiation of labor in sheep (Liggins et al. 1973). Therefore, the precise function(s) of progesterone, in particular, throughout pregnancy and in the preparation for and completion of parturition, has not yet been defined in any species.

Estrogen and progesterone have no documented direct effect on contractility, but regulate contractility through their actions on protein synthesis, on synthesis of intracellular and cell surface receptors, on phospholipid membrane structure, and on eicosanoid synthesis (Garfield 1979). The polarity of the distribution of $E R \alpha$ and $P R$ in the pregnant uterus is not required for mediating estrogen and progesterone physiological functions. Therefore, it is not surprising that there was no regional difference of either ER $\alpha$ or PR from the uterine fundus to the lower uterine segment.

In contrast to our observation with the steroid receptors, the labor-related elevation of OTR mRNA abundance in the fundus compared with the lower uterine segment suggests that OT exerts polarity in its effects on myometrial contractile force. This observation is consistent 

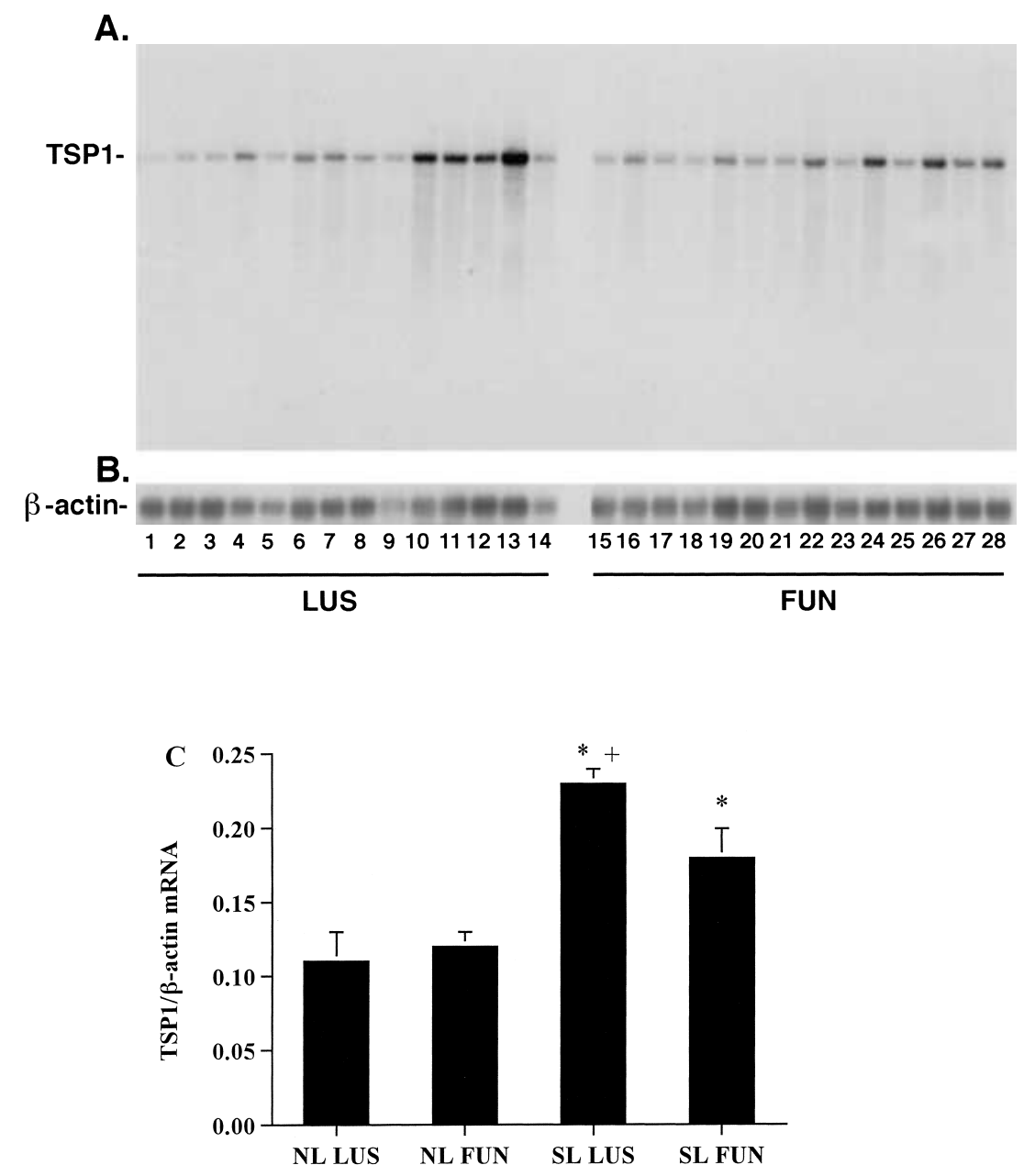

Figure 5 (A) Northern analysis of TSP1 mRNA in non-labor (NL) lower uterine segment (LUS; lanes 1-9) and NL fundus (FUN; lanes 15-23) compared with spontaneous labor (SL) LUS (lanes 10-14) and SL FUN (lanes 24-28). (B) The same blot was probed for $\beta$-actin. (C) Densitometric analysis of the ratio of TSP1 and $\beta$-actin mRNA in NL LUS and NL FUN (means \pm S.E.M.; $n=9$ for both groups) compared with SL LUS and SL FUN (means \pm S.E.M.; $n=5$ for both groups). TSP1 mRNA increased significantly in both LUS and FUN during SL $\left({ }^{\star} P<0 \cdot 05\right)$. In addition, SL LUS TSP1 mRNA was significantly higher than SL FUN TSP1 mRNA $(+P<0 \cdot 05)$.

with one previous report which used the binding activity measurement of a single human hysterectomy specimen, demonstrating that the increase in OTR numbers near term results in a gradient of expression, with the highest and lowest receptor concentrations found in the fundus and cervix respectively (Fuchs et al. 1984). This differential expression of OTR may be involved in directing the correct propagation of contractions from the fundus to the cervix during labor. We have recently reported a reduced contractile response of myometrium from the lower uterine segment tissues of the late-pregnant baboon to prostaglandin E2 which is paralleled by greater expression of inhibitory prostaglandin E2 receptor EP2 subtype, and less contractile EP3 subtype expression (Smith et al. 1998). These data from our laboratory and others (Fuchs et al. 1984, Adenantado et al. 1988) raise the possibility that the expressions of mCAPs are not only under mechanical or hormonal control, but are also spatially regulated.

Myometrial sensitivity to OT is enhanced dramatically at term and during parturition due, at least in part, to an increase in the concentration of OTR (Fuchs et al. 1983). Data from the rat (Ou et al. 1998) and sheep (Wu et al. 1999b) demonstrate increased OTR expression during labor in the stretched gravid horn compared with the unstretched non-gravid horn in unilaterally pregnant animals. These findings suggest that mechanical distension 
may be critical in regulating OTR mRNA levels during pregnancy and parturition. They are also compatible with stimulation of increased myometrial OTR mRNA by the increased uterine volume resulting from fetal growth as observed in the current study.

Our previous study in sheep (Wu et al. 1999a) and the present study, together with one previous report in pregnant women (Morimoto et al. 1998), indicate that increased myometrial TSP1 during labor is a common feature shared across species. The function of TSP1 in association with pregnancy and labor remains to be defined in relation to parturition. Both endogenous and exogenous TSP1 block blood vessel formation during physiological and pathological responses in which angiogenesis is a predominant feature (Good et al. 1990, Iruela-Arispe et al. 1991). Thus, increased myometrial TSP1 during labor may play a role in prevention of postpartum hemorrhage.

In summary, this is the first study to provide data in relation to regional distribution, gestation and labor on changes in mRNA for critical steroid receptor, peptide receptor and matrix protein mCAPs in the same animals in an extensively studied non-human primate. It is important that these changes were correlated to the status of myometrial contractility as monitored precisely and directly. There were differential changes of different mCAPs in relation to uterine topology, gestation and labor. The increased OTR mRNA associated with gestation may contribute to the increased uterine sensitivity to OT that occurs in preparation for labor. The higher OTR mRNA in the fundus compared with the lower uterine segment may be one of the mechanisms that provide polarity to the contraction of the uterus from the fundus to the lower uterine segment during labor. The observed increase of TSP1 mRNA in pregnant baboon myometrium during labor parallels findings in pregnant sheep and merits further study of its function in parturition. $\mathrm{ER} \alpha$ and $\mathrm{PR}$ mRNA in the fundus and lower uterine segment did not change through the period of gestation studied or during spontaneous labor.

\section{Acknowledgements}

This work was supported by NIH HD 21350.

\section{References}

Adenantado J, Bernal AL \& Turnbull A 1988 Topographical distribution of prostaglandin $\mathrm{E}$ receptors in human myometrium. British Journal of Obstetrics and Gynaecology 95 348-353.

Bergman MD, Schachter BS, Karelus K, Combatsiaris EP, Garcia T \& Nelson JF 1992 Up-regulation of the uterine estrogen receptor and its messenger ribonucleic acid during the mouse estrous cycle: the role of estradiol. Endocrinology 130 1923-1930.

Carson-Jurica MA, Schrader WT \& O’Malley BW 1990 Steroid receptor family: structure and functions. Endocrine Reviews $\mathbf{1 1}$ 201-220.
Challis JRG 1971 Sharp increase in free circulating oestrogen immediately before parturition in sheep. Nature 229208.

Challis JRG \& Lye SJ 1994 Parturition. In The Physiology of Reproduction, edn 2, ch 55, pp 985-1031. Eds E Knobil \& JD Neill. New York, USA: Raven Press.

Cho H, Ng PA \& Katzenellenbogen BS 1991 Differential regulation of gene expression by estrogen in estrogen growth-independent and -dependent MCF-7 human breast cancer cell sublines. Molecular Endocrinology 5 1323-1330.

Csapo AI 1975 The 'seesaw' theory of regulator mechanisms of pregnancy. American Journal of Obstetrics and Gynecology 121 $578-581$.

Fuchs AR, Periyasamy S, Alexandrova M \& Soloff MS 1983 Correlation between oxytocin receptor concentration and responsiveness to oxytocin in pregnant rat myometrium. Effect of ovarian steroids. Endocrinology 113 742-749.

Fuchs AR, Fuchs F, Husslein P \& Soloff M 1984 Oxytocin receptors in the human uterus during pregnancy and parturition. American Journal of Obstetrics and Gynecology 150 734-739.

Garfield RE 1979 Control of myometrial function in preterm versus term labor. Clinical Obstetrics and Gynecology 27 572-591.

Giussani DA, Jenkins SL, Mecenas CA, Winter JA, Honnebier MBOM \& Nathanielsz PW 1996 The oxytocin antagonist atosiban prevents androstenedione-induced myometrial contractions in the chronically instrumented, pregnant rhesus monkey. Endocrinology 137 3302-3307.

Good DJ, Polverini PJ, Rastinejad F, Le Beau MM, Lemons RS, Frazier WA \& Bouck NP 1990 A tumor suppressor-dependent inhibitor of angiogenesis is immunologically and functionally indistinguishable from a fragment of thrombospondin. PNAS 87 6624-6628.

Goodwin TM, Valenzuela GJ, Silver H \& Creasy G 1996 Dose ranging study of the oxytocin antagonist atosiban in the treatment of preterm labor. Obstetrics and Gynecology 88 331-336.

Green S, Walter P, Kumar V, Krust A, Bornert JM, Argos P \& Chambon P 1986 Human oestrogen receptor cDNA: sequence, expression and homology to V-erb-A. Nature 320 134-139.

Haluska GJ, West NB, Novy MJ \& Brenner RM 1990 Uterine estrogen receptors are increased by RU486 in late pregnant rhesus macaques but not after spontaneous labor. Journal of Clinical Endocrinology and Metabolism 70 181-186.

Iruela-Arispe ML, Bornstein P \& Sage H 1991 Thrombospondin exerts an antiangiogenic effect on cord formation by endothelial cells in vitro. PNAS 88 5026-5030.

Kuiper GG, Enmark JM, Pelto-Huikko E, Nilsson M \& Gustafasson JA 1996 Cloning of a novel estrogen receptor expressed in rat prostate and ovary. PNAS 93 5925-5930.

Liggins GC, Fairclough RJ, Grieves SA, Kendall JZ \& Knox SJ 1973 The mechanism of initiation of parturition in the ewe. Recent Progress in Hormone Research 29 111-149.

Lye S 1994 The initiation and inhibition of labor - toward a molecular understanding. Seminars in Reproductive Endocrinology 12 284-297.

Mecenas CA, Giussani DA, Owiny JR, Jenkins SL, Wu WX, Honnebier MBOM, Lockwood CJ, Kong L, Guller S \& Nathanielsz PW 1996 Production of premature delivery in pregnant rhesus monkeys by androstenedione infusion. Nature Medicine $\mathbf{2}$ 443-448.

Morgan MA, Silavin SL, Wentworth RA, Figueroa JP, Honnebier BOM, Fishburne JI \& Nathanielsz PW 1992 Different patterns of myometrial activity and 24-h rhythms in myometrial contractility in the gravid baboon during the second half of pregnancy. Biology of Reproduction 46 1158-1164.

Morimoto T, Head J, MacDonald PC \& Casey ML 1998 Thrombospondin-1 expression in human myometrium before and during pregnancy, before and during labor, and in human myometrial cells in culture. Biology of Reproduction 59 862-870. 
Nathanielsz PW 1998 Comparative studies on the initiation of labor. European Journal of Obstetrics, Gynecology and Reproductive Biology 78 127-132.

Nathanielsz PW, Wentworth RA, Jenkins SL, Mecenas CA, Giussani DA \& Honnebier MBOM 1994 Maternal and fetal endocrine regulation of the different patterns of myometrial contractility in the pregnant nonhuman primate. Seminars in Reproductive Endocrinology 12 314-322.

Nathanielsz PW, Honnebier MBOM, Mecenas C, Jenkins SL, Holland ML \& Demarest K 1997 Effect of the oxytocin antagonist atosiban (1-deamino-2-D-Tyr (OET)-Thr-8-Orn-vasotocin/ oxytocin) on nocturnal myometrial contractions, maternal cardiovascular function, transplacental passage, and fetal oxygenation in the pregnant baboon during the last third of gestation. Biology of Reproduction 57 320-324.

Nathanielsz PW, Jenkins SL, Tame JD, Winter JA, Guller S \& Giussani DA 1998 Local paracrine effects of estradiol are central to parturition in the rhesus monkey. Nature Medicine 4 456-459.

Novy MJ \& Haluska GJ 1994 New perspectives on estrogen, progesterone, and oxytocin action in primate parturition. In Basic Mechanisms Controlling Term and Preterm Birth, Ernst Schering Research Foundation Workshop 7, pp 162-195. Eds K Chwalisz \& RE Garfield. Berlin, Heidelberg, New York: Springer-Verlag.

Okulicz WC, Balsamo M \& Tast J 1993 Progesterone regulation of endometrial estrogen receptor and cell proliferation during the late proliferative and secretory phase in artificial menstrual cycles in the rhesus monkey. Biology of Reproduction 49 24-32.

Ou CW, Chen ZQ, Qi S \& Lye SJ 1998 Increased expression of the rat myometrial oxytocin receptor messenger ribonucleic acid during labor requires both mechanical and hormonal signals. Biology of Reproduction 59 1055-1061.

Simpson ER \& MacDonald PC 1981 Endocrinology of pregnancy. In Textbook of Endocrinology, edn 6, ch 8, pp 412-422. Ed. RH Williams. Philadelphia: WB Saunders Company.

Smith GCS, Baguma-Nibasheka M, Wu WX \& Nathanielsz PW 1998 Regional variations in contractile response to prostaglandins and prostanoid receptor messenger ribonucleic acid in pregnant baboon uterus. American Journal of Obstetrics and Gynecology 70 1545-1552.

Sparey C, Robson SC, Bailey J, Lyall F \& Europe-Finner GN 1999 The differential expression of myometrial connexin-43, cyclooxygenase- 1 and -2 , and $G_{s} \alpha$ proteins in the upper and lower segment of the human uterus during pregnancy and labor. Journal of Clinical Endocrinology and Metabolism 84 1705-1710.

Taylor NF, Martin MC, Nathanielsz PW \& Seron-Ferre M 1983 The fetus determines circadian oscillation of myometrial electromyographic activity in the pregnant rhesus monkey. American Journal of Obstetrics and Gynecology 146 557-567.

Thorburn GD, Hooper SB, Rice GE \& Fowden AL 1988 Luteal regression and parturition: a comparison. In Cellular and Integrative
Mechanisms in the Onset of Labour: What are the Research Priorities? pp 185-211. Eds D McNellis, JRG Challis, P MacDonald, PW Nathanielsz \& J Roberts. New York: Perinatology Press.

Wu WX, Myers DA \& Nathanielsz PW 1995 Changes in estrogen receptor mRNA in sheep fetal and maternal tissues during late gestation and labor. American Journal of Obstetrics and Gynecology 172 $842-855$

Wu WX, Derk JB, Nathanielsz PW \& Brenna JT 1996a The effect of glucocorticoids on estrogen receptor messenger ribonucleic acid in the pregnant ovine myometrium in vivo and in vitro. Biology of Reproduction 54 230-241.

Wu WX, Owiny JR \& Nathanielsz PW 1996 R Regulation of estrogen receptor mRNA and its peptide in the non-pregnant sheep uterus. Biology of Reproduction $\mathbf{5 5}$ 762-768.

Wu WX, Verbalis J, Hoffman G \& Nathanielsz PW 1996 c Characterization of oxytocin (OT) receptor (OTR) expression and distribution in the late pregnant sheep myometrium and endometrium. Endocrinology 137 722-728.

Wu WX, Unno N, Ma XH \& Nathanielsz PW 1998 Inhibition of prostaglandin production by nimesulide is accompanied by changes in expression of the 'cassette' of uterine labor related genes in the pregnant sheep. Endocrinology 139 3096-3103.

Wu WX, Zhang Q, Ma XH, Unno N \& Nathanielsz PW 1999a Suppression subtractive hybridization identified a marked increase in thrombospondin-1 associated with parturition in pregnant sheep myometrium. Endocrinology 149 2364-2371.

Wu WX, Ma XH, Toshi Y, Shinozuka N \& Nathanielsz PW 1999 b Differential expression of myometrial (Myo) oxytocin receptor (OTR) and prostaglandin $\mathrm{H}$ synthase (PGHS)2, but not estrogen receptor (ER) $\alpha$ and heat shock protein (Hsp) 90 mRNA between the pregnant horn $(\mathrm{PH})$ and non-pregnant horn $(\mathrm{NPH})$ in sheep during betamethasone induced labor (BL). Endocrinology 140 5712-5718.

Wu WX, Ma XH, Smith GCS \& Nathanielsz PW 2000 Differential distribution of ER $\alpha$ and ER $\beta$ mRNA in intrauterine tissues of the pregnant rhesus monkey. American Journal of Physiology 278 C190-C198.

Zeeman GG, Khan-Dawood FS \& Dawood MY 1997 Oxytocin and its receptor in pregnancy and parturition: current concepts and clinical implications. Obstetrics and Gynecology 89 873-883.

Zingg HH, Rozen F, Chu K, Larcher A, Arslan A, Richard S \& Lefebvre D 1995 Oxytocin and oxytocin receptor gene expression in the uterus. Recent Progress in Hormone Research $\mathbf{5 0}$ $255-272$.

Received 2 April 2001

Accepted 28 August 2001 